\title{
固有振動数の振幅依存性に基づく伝統木造建物の最大応答予測法 MAXIMUM RESPONSE EVALUATION OF TRADITIONAL WOODEN BUILDINGS BASED ON AMPLITUDE DEPENDENCY OF NATURAL FREQUENCY
}

\author{
杉野未奈*, 多幾山法子**, 大西良広***, 林 康 裕**** \\ Mina SUGINO, Noriko TAKIYAMA, Yoshihiro ONISHI \\ and Yasuhiro HAYASHI
}

\begin{abstract}
The objective of this study is to establish a method of evaluating the maximum response of traditional wooden buildings during strong ground motions by microtremor measurements which is used to evaluate their natural frequency. To clarify the relationship between the maximum response and the vibration characteristics, the shaking table test of wooden frame structure is conducted. Using response spectra method, the maximum response considering the damage by former earthquakes is evaluated from the expression of the amplitude dependency of the vibration characteristics. We confirm this method can evaluate the maximum response approximately.
\end{abstract}

\section{Keywords: Traditional Wooden Buildings, Shaking Table Test, Microtremor Measuring, Estimation of Maximum Response, Response Spectrum Method 伝統木造建物，振動台実験，常時微動計測，最大応答予測，応答スペクトル法}

\section{1.はじめに}

我国には、地域の気候や風土に適した伝統構法による木造建物が 数多く残っている。しかし、1995 年に発生した兵庫県南部地震では、 多数の古い木造建物が倒壊して多くの人命が失われた。このため、 同地震以降、古い木造建物の耐震性向上が重要な地震対策と考えら れているが、耐震補強は必ずしも十分に進んでいるとは言い難い。 耐震補強を促進するためには、膨大な数の古い木造建物の中から耐 震性能の低い建物を効率的に選び出し、住まい手が納得できるよう な耐震補強の効果を提示する必要がある。そこで、本研究では、伝 統木造建物を対象として、簡便・低コスト・非破壊・短時間で実施 可能な常時微動計測より得られる固有振動数を基に、地震応答を簡 易予測する方法を構築する。

本研究で提案する伝統木造建物の最大応答の予測法は、限界耐力 計算 1 ), 2), 3) の計算過程と同様に応答スペクトル法を用いる(図 1)。限 界耐力計算においては、建物を 1 自由度系に置換して、その復元力 特性の骨格曲線から変形量に応じた等価な固有周期を求め、減衰定 数とともに、応答スペクトル法を用いて最大応答の推定を行う(図 2 )。本研究で提案する方法は、復元力特性や骨格曲線を意識するこ となく、極微小変形から大変形時における固有振動数及び減衰定数 の変化（以下、固有振動数及び減衰定数の振幅依存性と呼ぶ）を用 いて最大応答を予測する点に特徵がある。これは、限界耐力計算に おいて地盤の地震動増幅率を算定する際に、土質種別を砂質土と粘 性土に分けて地盤の剛性低下曲線と減衰増大曲線を定義し、表層地
盤の応答を予測する手法1), 2), 4) に対応している。

ここで、木造建物の固有振動数の変化を用いた最大予測法を構築 寸ることの意義は、下記の通りである。

a) 固有振動数の振幅依存性を把握できれば、常時微動計測によって 計測可能な固有振動数を建物の最大応答予測に利用することが可 能となる。特に、通常の耐震診断と異なり、最も時間と労力を要 する重量算定を行う必要が無い。すなわち、常時微動計測を簡易 耐震診断、あるいは、耐震診断が必要な建物の効率的な選定に用 いる事が可能となる。

b) 固有振動数の振幅依存性を用いる事で、地震動や地盤の卓越振動 数と建物応答の対応関係を容易に把握可能である。

そこで本研究では、上記のような応答予測法を構築するために、 正弦波パルスを入力した単位木造軸組架構の振動台実験と常時微動 計測を実施し、下記の目標を達成する。

1 ) 極微小変形から大変形領域に至るまでの固有振動数の振幅依存性 を定量化するため、実験データの蓄積を行う。

2) 地震被害を経験すると固有振動数は低下寸るが、経験変形量に忘 じた低下量を把握する。

なお、振動台実験において入力として正弦波パルスを用いる利点 は、パルス周期を変化させることで単位木造軸組の応答変形を容易 に制御可能であり、また、正弦波パルス入力終了後に生じる自由振 動部分を分析可能であることから、固有振動数の振幅依存性と経験 変形量に応じた固有振動数の低下を定量的に把握可能な点にある。

\footnotetext{
本稿は文献15），16）を再構成し，加筆・修正したものである。 * 京都大学大学院工学研究科建築学専攻 修士課程

** 京都大学大学院工学研究科建築学専攻 助教・博士 (工学)

*** 京都大学大学院工学研究科建築学専攻 准教授・博士 (工学)

**** 京都大学大学院工学研究科建築学専攻 教授. 工博
}

Graduate Student, Dept. of Architecture and Architectural Eng., Kyoto Univ. Research Assoc., Dept. of Architecture and Architectural Eng., Kyoto Univ., Dr. Eng. Assoc. Prof., Dept. of Architecture and Architectural Eng., Kyoto Univ., Dr. Eng.

Prof., Dept. of Architecture and Architectural Eng., Kyoto Univ., Dr. Eng. 


\section{2. 最大応答の簡易評価}

\section{1 既往の評価法}

本章では、最大応答変形角の簡易評価法に用いる応答スペクトル 法 5), 6)の概念を説明する。応答スペクトル法は、想定される地震動の 加速度応答スペクトル $S_{a}$ と直接比較可能なように、建物特性を等価 な性能等価応答スペクトル $S_{a e}$ に変換することで、 $S_{a}$ と $S_{a e}$ の交点から 最大応答変形角 $R$ を求める方法である(図 1 )。式 $(1)$ に既往の評価法 による $S_{a e}$ を示す。式(2)に示す加速度低減率 $F_{h}$ は、正弦波パルス 1 波 の場合は $\alpha=\pi^{7)}$, 告示波の場合には $\alpha=10^{1)}$, 2) とする。

$$
\begin{aligned}
& S_{a e}\left(R, R_{y}, C_{y}\right) F_{h}(h(R))=Q\left(R, R_{y}, C_{y}\right) / M \\
& F_{h}(h(R))=(1+0.05 \alpha) /(1+h(R) \cdot \alpha)
\end{aligned}
$$

(1)式に示したように、限界耐力計算法などの既往の応答スペクトル 法では、建物の復元力特性の骨格曲線に相当寸る $Q\left(R, R_{y}, C_{y}\right)$ と減衰定 数 $h(R)$ を用いる(図2)。ここで、 $R_{y}$ は降伏変形角、 $C_{y}$ は降伏せん断 力係数である。また、過去の被災経験による剛性の低下のような建 物特性の変化は考慮できていない。

\section{2 提案評価法}

本研究では、骨格曲線の替わりに、建物特性を建物の固有振動数 $f\left(R, R_{d}, f_{0}\right)$ 及び減衰定数 $h(R)$ の振幅依存性で表し、地震動に対する最 大応答変形角 $R$ を評価する方法を提案する(図 3 )。被災経験後に実施 寸る常時微動計測から得られる固有振動数 $f_{m}$ は建設時点の固有振動 数 $f_{0}$ より低下寸る。そこで、過去の地震で経験した最大忘答変形角 $R_{d}$ より小さい範囲での $f\left(R, R_{d}, f_{0}\right)$ に修正を加えることで被災経験を考 慮した建物特性を表現する。以上より、 $f\left(R, R_{d}, f_{0}\right), h(R)$ から求めた $S_{a e}$ を式(3)に示す。

$$
S_{a e}\left(R, R_{d}, f_{0}\right) F_{h}(h(R))=\left(2 \pi f\left(R, R_{d}, f_{0}\right)\right)^{2} R H
$$

提案する評価式に用いる固有振動数 $f$ 及び減衰定数 $h$ の振幅依存性を 把握するために、木造軸組架構の振動台実験を行い、振動特性の評 価式を作成する。

\section{3. 木造軸組架構の振動台実験}

\section{1 実験概要}

\section{(A) 試験体}

試験体は図 4 に示すような 6 種類の単位軸組架構を 2 構面平行に 配置し、天板（構造用合板＋小梁）及び筋交い（ステンレス製）で 結合したものである。試験体は土台を振動台上の架台にアンカーボ ルトで固定し、天板の上に上載重量（おもり）を載せる。試験体の 諸元を表 1 に示寸。上載荷重は、試験体の柱脚部に浮き上がりが生 じないよう各試験体の最大耐力を既往の静的載荷実験結果例えば8，99か ら想定して決定している。差鴨居はベイマツE 110 (断面寸法 $120 \times$
$270 \mathrm{~mm}$ ）を用いる。柱と桁および土台の接合部は、軸組・下見板・ 全壁・垂壁試験体では短ほぞ（ほぞ寸法 $30 \times 84 \times 52.5 \mathrm{~mm}$ ）に加え て両面山型プレートで留める仕様とし、差鴨居・垂壁差鴨居試験体 は長ほぞ（柱頭ほぞ寸法 $30 \times 80 \times 150 \mathrm{~mm}$ 、柱脚ほぞ寸法 $30 \times 80 \times$ $100 \mathrm{~mm}$ ） $15 \mathrm{~mm}$ 角の込栓（材種 : 米松）で留める仕様としている。 乾式パネルは $26 \mathrm{~mm}$ 厚のパネルを受け材仕様で施工している ${ }^{10)}$ 。

(B) 入力波

加振は一方向加振とし、変位制御で加振する。加振スケジュール を表 2 に示す。入力波は正弦波パルス及び告示波を用いる。

正弦波パルスは、加速度波形が正弦波 1 波となっており、その変 位波形を図 5(a)に示寸。正弦波パルスはパルス周期 $T_{p}=0.5,1.0,2.0,3.0 \mathrm{~s}$ とし、最大振動台変位 $D_{0}$ を $250 \mathrm{~mm}$ で一定とする。ただし、 $T_{p}=0.5 \mathrm{~s}$ の ときは応答が過大となる可能性があったため $200 \mathrm{~mm}$ としている。正 弦波パルスを用いる利点は、パルス周期 $T_{p}$ を変化させることで最大 応答を制御できること、加振終了時間が明らかであるため、明瞭な 自由振動波形を取り出せること、が挙げられる。以上より、固有振 動数と減衰定数の振幅依存性を把握することができる。また、表 2 の No.2 と 8 のように、同一の入力波で 2 度加振するのは、被災の有無 （大変形を経験したか）による建物応答の変化を調べるためである。 入力波 No.4 $\left(T_{p}=1.0 \mathrm{~s}\right)$ では、軸組・下見板・全壁試験体は加振中に試験 体同士が衝突しているので、本研究の検討から除外寸る。

また、継続時間が長い告示波を用い、正弦波パルスとの比較を行 う。ここで告示波は、解放工学的基盤上での安全限界時の標準加速 度応答スペクトル（減衰 $5 \%$ ）に合うように、ランダム位相を用いて 作成した模擬地震動（継続時間 165 秒）と寸る。本研究では、倍率を 変えて 4 種類入力する。変位波形を図 $5(\mathrm{~b})$ に示寸。

(C) 計測方法

本論文の分析に用いた計測機器の設置位置を図 6 に示す。おもり 上及び振動台上の加振方向に加速度計をそれぞれ 2 台、桁位置及び各 構面の振動台上の加振方向に変位計をそれぞれ 2 台設置している。サ ンプリング周波数は $1000 \mathrm{~Hz}$ であり、計測後に $100 \mathrm{~Hz}$ に変換して分析 する。計測值は 2 台の計測機器の平均值とし、計測データのノイズを 除去するためにフィルタをかける。加速度は $20 \mathrm{~Hz}$ 、変位は下見板・ 全壁試験体は $10 \mathrm{~Hz}$ 、他の試験体は $3 \mathrm{~Hz}$ 以上を $\cos$ 関数で減少させる ローパスフィルタをかける。実験の様子を図 7 に示す。

また、各加振の前後に常時微動計測を行う。GPS アンテナを用い て 2 台の振動計の同期をとり、1 台を振動台上に、1 台を試験体上に 設置して同時計測を行う。計測は、サンプリング周波数 $100 \mathrm{~Hz}$ 、ロー パスフィルタ $5 \mathrm{~Hz}$ 、計測時間 5 分間とする。試験体の固有振動数を求 めるために、フーリエ変換後、標本のアンサンブル平均を行い、Parzen

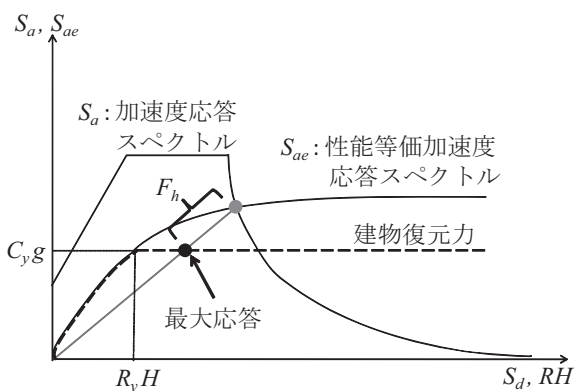

図 1 応答スペクトル法の概念

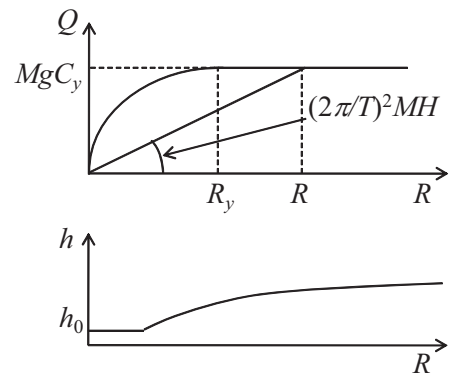

図 $2 Q\left(R, R_{y}, C_{y}\right)$ 関係と $h(R)$ 関係

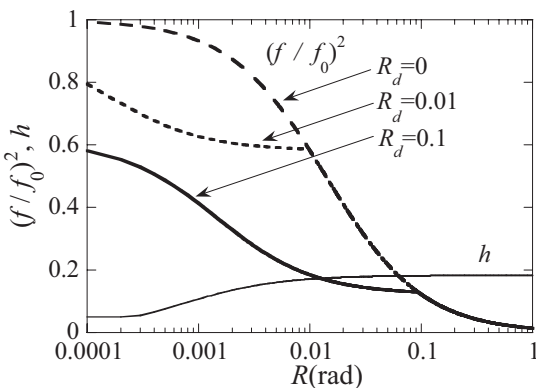

図 $3 f\left(R, R_{d}, f_{0}\right)$ 関係と $h(R)$ 関係 
Windowにより $0.1 \mathrm{~Hz}$ の Window 幅で平滑化を行う。試験体上で得られ たフーリエスペクトルを振動台上の計測で得たフーリエスペクトル で除して、フーリエスペクトル比を求める。求めたフーリエスペク トル比のピーク值を固有振動数とする。表 1 の実験前固有振動数 $f_{0}$ は、実験前(入力波 No.1 加振前) に常時微動計測から得た固有振動数 である。

\section{2 実験結果}

(A) 層間変形角応答波形

層間変形角は、試験体の相対変位を柱高さで除したものとし、そ の時刻歴波形を図 8 に示寸。図 8(a),(b) に示すように試験体の固有振 動数と正弦波パルスのパルス周期の関係により、試験体の最大応答 は大きく変化することが分かる。また、図 8(c)のように同じ入力波・
試験体であっても 2 回目の加振（被災経験後）のほうが応答が大き く、固有振動数が低いことが確認できる。

(B) 荷重 - 変形角関係

慣性力と層間変形角から、単位構面の荷重 - 変形角関係を求める。 図 9 は各試験体における正弦波パルス加振の 8 回分の荷重 - 変形角関 係を重初描いている。軸組や差鴨居、垂壁差鴨居、垂壁の試験体に 比べて、下見板や全壁の試験体は初期剛性が高く、より小さい変形 角から剛性が低下し、最大耐力に達していることが分かる。

\section{(C) 固有振動数}

固有振動数は、常時微動計測及び加速度計の計測值より求めた試 験体下部に対する上部のフーリエスペクトル比のピーク值より推定 する。本論文では、常時微動計測による加振前後のピーク振動数 $f_{m}$ と

表 1 試験体諸元

\begin{tabular}{|c|c|c|c|c|c|c|}
\hline 試験体 & 軸組 & 下見板 & 全壁 & 差鴨居 & 垂壁差鴨居 & 垂壁 \\
\hline 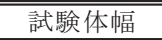 & $1820 \mathrm{~mm}$ & $1820 \mathrm{~mm}$ & $1820 \mathrm{~mm}$ & $1820 \mathrm{~mm}$ & $1820 \mathrm{~mm}$ & $1820 \mathrm{~mm}$ \\
\hline 柱高さ & $2625 \mathrm{~mm}$ & $2625 \mathrm{~mm}$ & $2625 \mathrm{~mm}$ & $2610 \mathrm{~mm}$ & $2610 \mathrm{~mm}$ & $2625 \mathrm{~mm}$ \\
\hline 柱径 & $105 \mathrm{~mm}$ 角 & $105 \mathrm{~mm}$ 角 & $105 \mathrm{~mm}$ 角 & $120 \mathrm{~mm}$ 角 & $120 \mathrm{~mm}$ 角 & $105 \mathrm{~mm}$ 角 \\
\hline 柱材種 & スギE70 & スギE70 & スギE70 & スギE70 & スギE70 & スギE70 \\
\hline $\begin{array}{c}\text { 壁面 } \\
\text { 耐力要素 }\end{array}$ & なし & 下見板 & \begin{tabular}{|c|}
$\begin{array}{c}\text { 乾式パネル } \\
\text { (片面) }\end{array}$ \\
\end{tabular} & なし & \begin{tabular}{|c|}
$\begin{array}{c}\text { 乾式パネル } \\
\text { (両面) }\end{array}$ \\
\end{tabular} & \begin{tabular}{|c|}
$\begin{array}{c}\text { 乾式パネル } \\
\text { (片面) }\end{array}$ \\
\end{tabular} \\
\hline 上載重量 & $22.0 \mathrm{kN}$ & $22.6 \mathrm{kN}$ & $32.8 \mathrm{kN}$ & $32.5 \mathrm{kN}$ & $23.4 \mathrm{kN}$ & $22.6 \mathrm{kN}$ \\
\hline $\begin{array}{c}\text { 実験前 } \\
\text { 固有振動数 } f_{0}\end{array}$ & $0.9 \mathrm{~Hz}$ & $5.6 \mathrm{~Hz}$ & $4.8 \mathrm{~Hz}$ & $1.4 \mathrm{~Hz}$ & $1.8 \mathrm{~Hz}$ & $1.5 \mathrm{~Hz}$ \\
\hline 損傷状態 & $\begin{array}{c}\text { 接合部周辺のめ } \\
\text { こみと割裂 }\end{array}$ & $\begin{array}{l}\text { 下見板のずれ、 } \\
\text { 釷の抜け・緩み }\end{array}$ & \begin{tabular}{|c|} 
荒壁パネルのひ \\
び割れ、 \\
土台の割裂 \\
\end{tabular} & \begin{tabular}{|c|} 
鼻栓の折損、差 \\
鴨居の柱からの \\
離間
\end{tabular} & \begin{tabular}{|c|}
$\begin{array}{c}\text { 鼻检の折損、差 } \\
\text { 鴨居の柱からの } \\
\text { 離間 }\end{array}$ \\
\end{tabular} & \begin{tabular}{|c|} 
接合部周辺のめ \\
こみと割裂
\end{tabular} \\
\hline
\end{tabular}

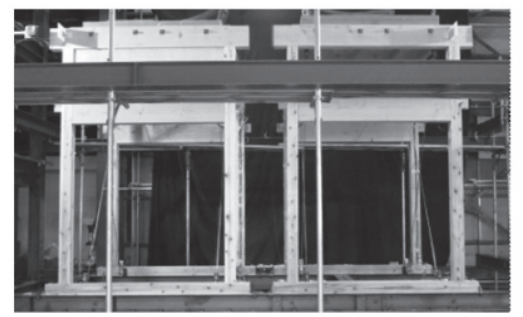

図 7 実験風景

（左：差鴨居垂壁、右：差鴨居）

表 2 加振スケジュール

\begin{tabular}{|l|l|l|l|l|}
\hline No. & 入力波 & $T_{p}(\mathrm{~s})$ & $D_{0}(\mathrm{~mm})$ & 倍率 $(\%)$ \\
\hline \hline
\end{tabular}

\begin{tabular}{|c|c|c|c|c|}
\hline 1 & \multirow{8}{*}{$\begin{array}{l}\text { 正弦波 } \\
\text { パルス }\end{array}$} & 3.0 & \multirow{4}{*}{250} & \multirow{8}{*}{-} \\
\hline 2 & & 2.0 & & \\
\hline 3 & & 1.0 & & \\
\hline 4 & & 1.0 & & \\
\hline 5 & & 0.5 & \multirow{2}{*}{200} & \\
\hline 6 & & 0.5 & & \\
\hline 7 & & 1.0 & \multirow{2}{*}{250} & \\
\hline 8 & & 2.0 & & \\
\hline 9 & \multirow{4}{*}{ 告示波 } & \multirow{4}{*}{-} & 36 & 20 \\
\hline 10 & & & 90 & 50 \\
\hline 11 & & & 125 & 70 \\
\hline 12 & & & 179 & 100 \\
\hline
\end{tabular}

$T_{p}$ : パルス周期

$D_{0}$ : 最大振動台変位

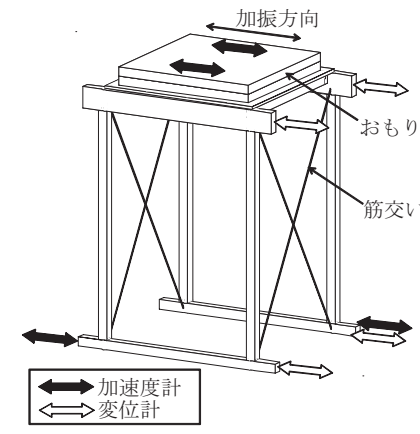

図 6 計測位置

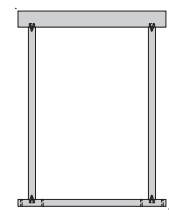

(a) 軸組試験体

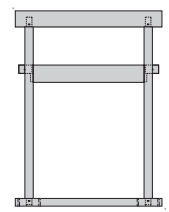

(d) 差鴨居試験体

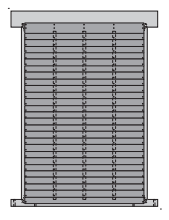

(b) 下見板試験体

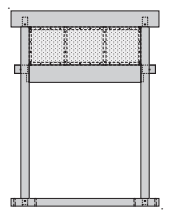

(e) 垂壁差鴨居試験体

図 4 試験体一覧

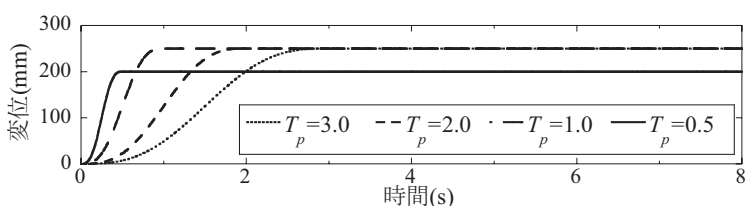

(a) 正弦波パルス

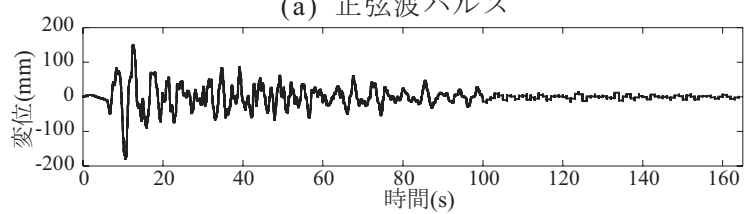

(b) 告示波

図 5 入力波

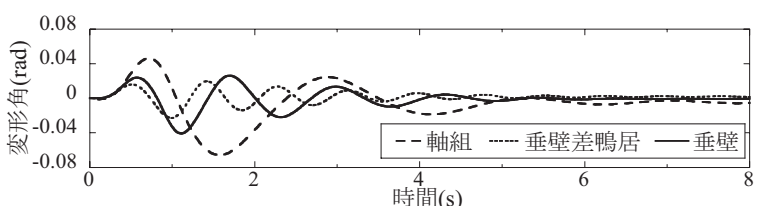

(a) 試験体種類 (No.3 $\left.T_{p}=1.0\right)$

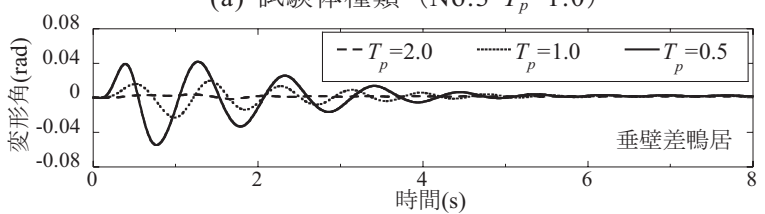

(b) パルス周期（被災経験なし）

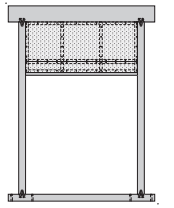

(f) 垂壁試験体

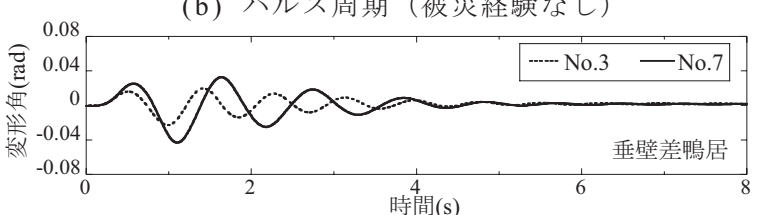

(c) 被災経験による違い $\left(T_{p}=1.0\right)$

図 8 層間変形角の時刻歴応答（正弦波パルス） 
加速度計による加振中のピーク振動数 $f_{e}$ をする。垂壁差鴨居試験体 の正弦波パルス No.3 の加振中及び加振前後のフーリエスペクトル比 を図 10 に示寸。このように、加振後の $f_{m}$ は加振前の $f_{m}$ よりも減少し ており、被災経験によって固有振動数が低下していることが分かる。 また、加振中の $f_{e}$ が加振前後の固有振動数よりも小さいことから、固 有振動数は建物が変形している時に低下寸る、つまり固有振動数に は振幅依存性があると考えられる。

また、正弦波パルス加振の場合、加振中の $f_{e}$ から加振後の $f_{m}$ への固 有振動数の推移を加振終了後の自由振動から求めることができる。図 11 (a)のように加振終了以降の応答波形のピーク間隔から 1 周期ごと に求めた自由振動中の固有振動数 $f_{f i}(i=1,2,3 \ldots)$ と、その時の変形角 $R_{f i}$ と の関係を図 11(b)に示寸。 $R_{f i}$ が減少するにつれ $f_{f i}$ は増加し、 $f_{e}$ から $f_{m}$ に 漸近することが分かる。ここでは、固有振動数 $f$ は、表 1 に示寸実験 前固有振動数 $f_{0}$ で無次元化したものを 2 乗して剛性比としている。 (D) 減衰定数

加振中の減衰定数 $h_{e}$ は、エネルギーの釣り合い11)から式(4)を用い て求める。

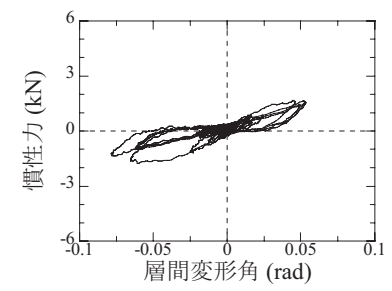

(a) 軸組試験体

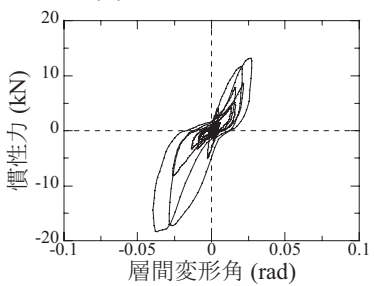

(d) 全壁試験体

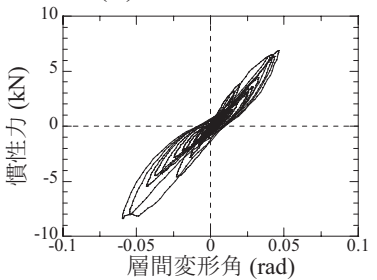

(f) 垂壁差鴨居試験体

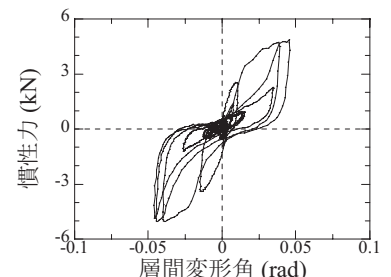

(b) 下見板試験体

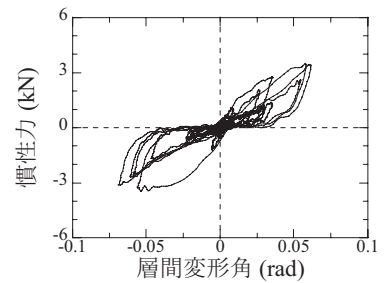

(e) 差鴨居試験体

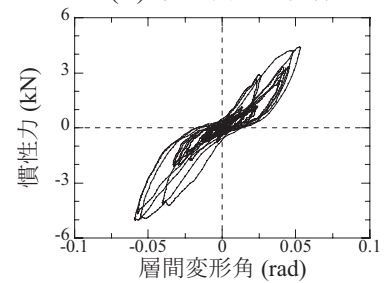

（g）垂壁試験体

図 9 荷重 - 変形角関係

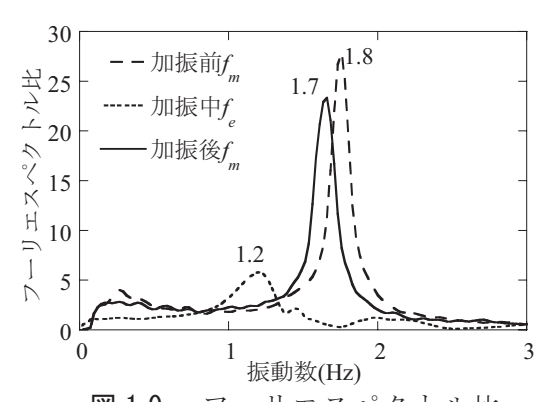

図 10 フーリエスペクトル比

（垂壁差鴨居 No.3 $T_{p}=1.0$ )

$$
h_{e}=\frac{-\int_{0}^{T} \ddot{x} \dot{y} d t}{2 \cdot 2 \pi f_{e} \int_{0}^{T} \dot{y}^{2} d t} \quad\left(\begin{array}{c}
\ddot{x}: \text { 絶対地動加速度 } \\
\dot{y}: \text { 相対速度 } \\
T: \text { :計測時間 }
\end{array}\right)
$$

加振前後の常時微動の減衰定数 $h_{m}$ は、常時微動計測結果から RD 法 12)を用いて求める。RD 法の適用例を図 12 に示す。

また、正弦波パルスの場合は、固有振動数と同様に、図 11 (a) の忘 答波形のピーク振幅から対数減衰率を用いて減衰定数の振幅依存性 の推移を求める。図11(b)のように、 $R_{f i}$ が減少するにつれ $h_{f i}$ も減少し、 $h_{e}$ から $h_{m}$ に漸近することが分かる。

\section{4. 振動特性評価式}

\section{1 評価式の概要}

本章では、応答スペクトル法に適用して最大応答を求めるため、 固有振動数及び減衰定数の振幅依存性の評価式を提案する。固有振 動数の振幅依存性は式(5)、減衰定数の振幅依存性は式(10)で表し (図 3)、式(5),(10)中の各変数は、式(6) (9)及び式(11)から求める。

$$
\begin{aligned}
& K\left(R, R_{d}\right)=\min \left\{K_{e}(R), K_{d}\left(R, R_{d}\right)\right\} \\
& K_{e}(R)=\left(f_{e} / f_{0}\right)^{2}=1 /\left(1+R / R_{0.5 e}\right) \\
& K_{m}(R)=\left(f_{m} / f_{0}\right)^{2}=1 /\left(1+R / R_{0.5 m}\right) \\
& K_{f}\left(R, R_{d}\right)=\left\{\left(f_{f} / f_{0}\right)^{2}-K_{e}\left(R_{d}\right)\right) /\left(K_{m}\left(R_{d}\right)-K_{e}\left(R_{d}\right)\right) \\
& =1 /\left\{1+\left(R / R_{d}\right) / R_{0.5 f}\right\} \\
& K_{d}\left(R, R_{d}\right)=\left\{K_{m}\left(R_{d}\right)-K_{e}\left(R_{d}\right)\right\} \cdot K_{f}(R)+K_{e}\left(R_{d}\right) \\
& h(R)=\max \left\{h_{0}, h_{f}(R)\right\} \\
& h_{f}(R)=h_{\max }\left\{R /\left(R+R_{0.5 h}\right)\right\}
\end{aligned}
$$

ここで振幅依存性の評価式は、代表的な土の非線形モデルとして用 いられる Hardin-Drnevich モデル（せん断歪 - せん断剛性比関係とせん 断歪 - 減衰定数関係) ${ }^{13)}$ を参考としている。ただし、Hardin-Drnevich モ デルでのせん断歪 - せん断剛性比関係と対応させるために、本研究で は固有振動数 $f$ を実験前の固有振動数 $f_{0}$ で無次元化して 2 乗したもの を用い、これを剛性比と考えている。また、 $R_{d}$ は過去に経験した最 大変形角であり、式(5)は被災経験が無い場合の剛性比は $K_{e}$ で、被災 経験がある場合には、 $R<R_{d}$ では剛性比が $K_{d}$ に低下することを表して いる。

式(5) (11) 中で、振動台実験結果を用いて回帰するパラメータは 表 3 に示寸 5 つで、以下のように回帰を行う。はじめに、加振中の

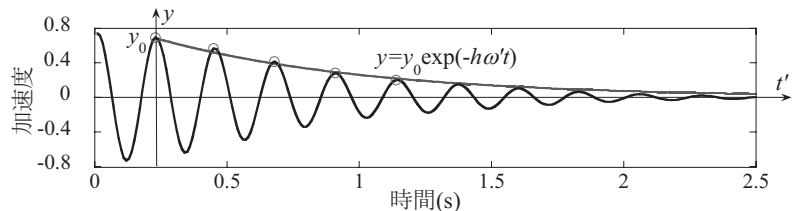

図 $12 \mathrm{RD}$ 法（全壁試験体 正弦波パルス No.4 $T_{p}=1.0$ 加振後）

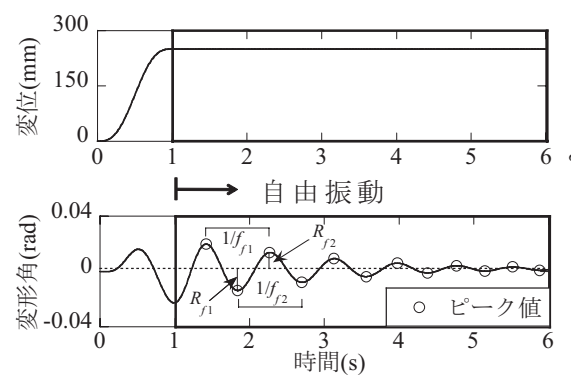

(a) 入力波（上）、応答波形（下）
図 11 加振後自由振動（垂壁差鴨居試験体 正弦波パルスNo.3 $T_{p}=1.0$ )

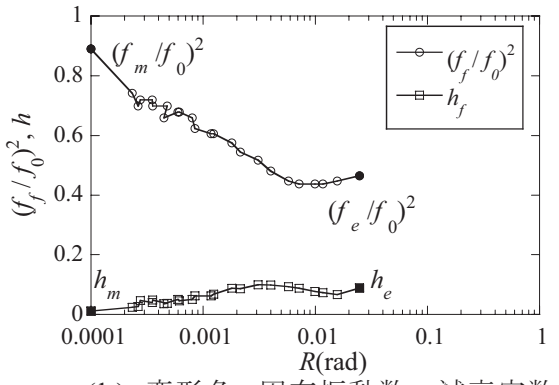

(b) 変形角 - 固有振動数・減衰定数 
ピーク振動数 $f_{e}$ と最大変形角 $R$ の関係を式 $(6)$ を用いて回帰して $R_{0.5 e}$ を求める。次に、加振後の常時微動のピーク振動数 $f_{m}$ と最大変形角 $R$ の関係を式(7)を用いて回帰し、 $R_{0.5 m}$ を決定する。ただし、以上の 2 つのパラメータの回帰には $R_{d}<R$ が成立する加振のみを用いる。

また、前章の図 11 (b) で示したように、各加振での自由振動中の固 有振動数 $f_{f}$ は、加振中のピーク振動数 $f_{e}$ から加振後のピーク振動数 $f_{m}$ に漸近する。ここでは、自由振動中の変形角 - 固有振動数関係（図 11(b)）が、被災経験による剛性の低下を表現していると考え、式(8) を用いて表現する。そして、式(6)，(7)に $R_{d}$ を代入した $K_{e}\left(R_{d}\right), K_{m}\left(R_{d}\right)$ を既知とし、式 $(8)$ を回帰して $R_{0.5 f}$ を求める。

一方、減衰定数 $h(R)$ についても、図 $11(\mathrm{~b})$ のように自由振動中の $h_{f i}$

は、加振中の減衰定数 $h_{e}$ から加振後の減衰定数 $h_{m}$ に漸近するので、 式(11)を用いて減衰定数の振幅依存性を回帰し、 $h_{\max }, R_{0.5 h}$ を決定する。 なお、式(10)中の $h_{0}$ は、減衰定数の下限值である。

\section{2 固有振動数の変化}

正弦波パルス入力の振動台実験の結果を用いて上記の固有振動数 の振幅依存性評価式を算定した結果について説明する。ここで、木

表 3 変形角 - 固有振動数関係

\begin{tabular}{|c|c|c|c|c|c|}
\hline 試験体 & $R_{0.5 e}$ & $R_{0.5 m}$ & $R_{0.5 f}$ & $R_{0.5 h}$ & $h_{\max }$ \\
\hline \hline $\begin{array}{c}\text { 軸組・差鴨居・ } \\
\text { 垂壁差鴨居・垂壁 }\end{array}$ & 0.014 & 0.16 & 0.015 & 0.00071 & 0.18 \\
\hline $\begin{array}{c}\text { 下見板 } \\
\text { ·全壁 }\end{array}$ & $\begin{array}{c}(0.0028) \\
0.00090\end{array}$ & 0.029 & 0.0024 & 0.00015 & 0.33 \\
\hline
\end{tabular}

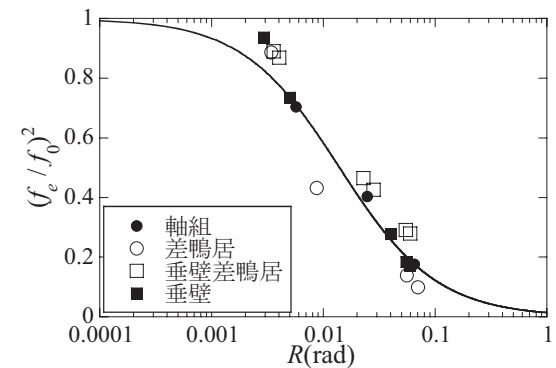

(a) 加振中のピーク振動数 $f_{e}$

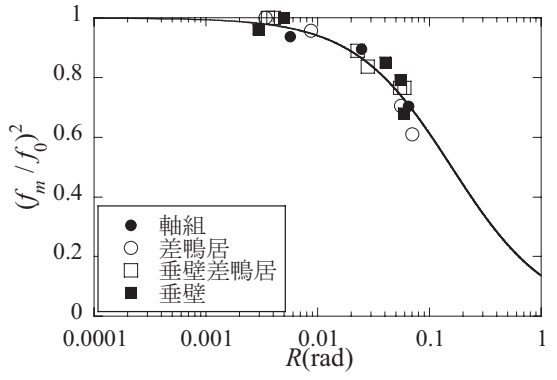

(b) 常時微動のピーク振動数 $f_{m}$

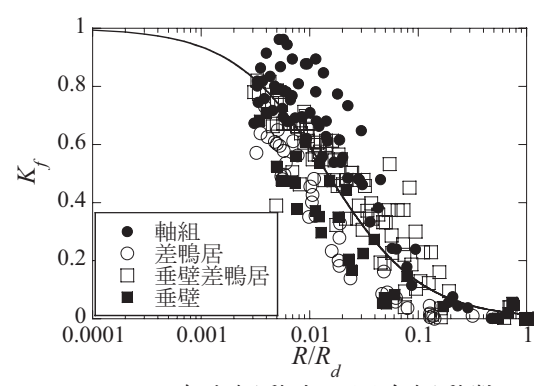

(c) 自由振動中の固有振動数 $f_{f}$

図 13 変形角 - 固有振動数関係【軸組・差鴨居 - 垂壁差鴨居 - 垂壁試験体】

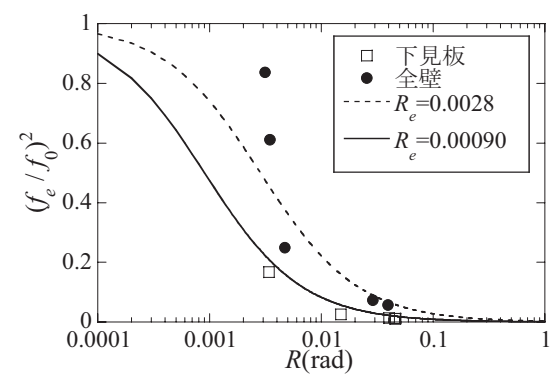

(a) 加振中のピーク振動数 $f_{e}$

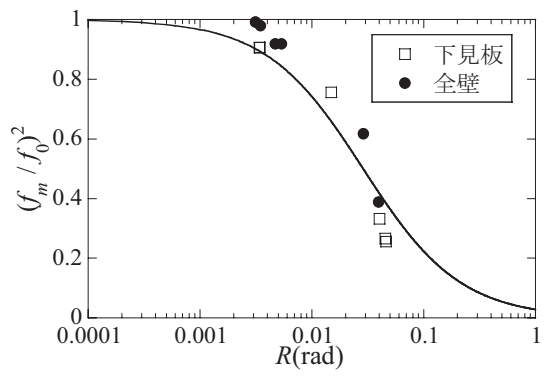

(b) 常時微動のピーク振動数 $f_{m}$

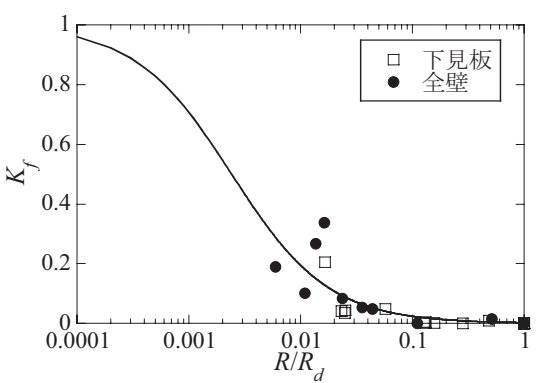

(c) 自由振動中の固有振動数 $f_{f}$

図 14 変形角 - 固有振動数関係【下見板 - 全壁試験体】

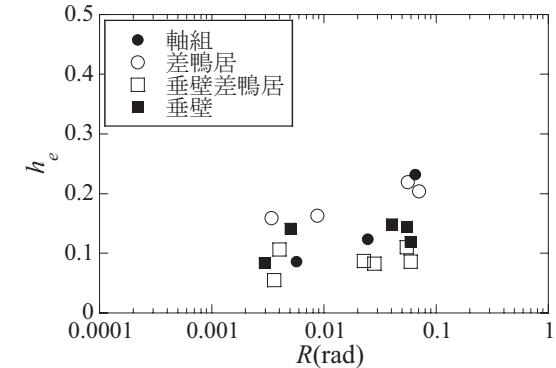

(a) 加振中の減衰定数 $h_{e}$

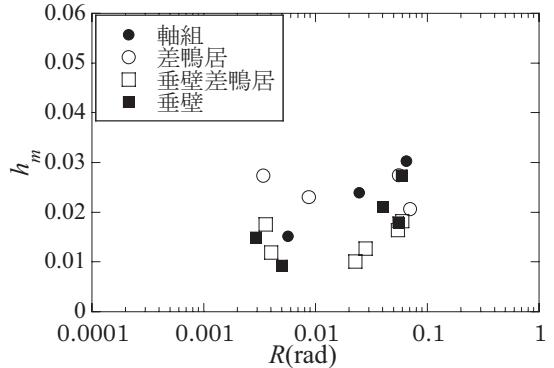

(b) 常時微動の減衰定数 $h_{m}$

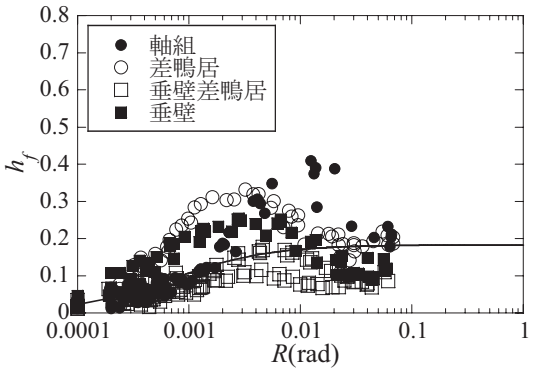

(c) 自由振動中の減衰定数 $h_{f}$

図 15 変形角 - 減衰定数関係【軸組 - 差鴨居 - 垂壁差鴨居 - 垂壁試験体】

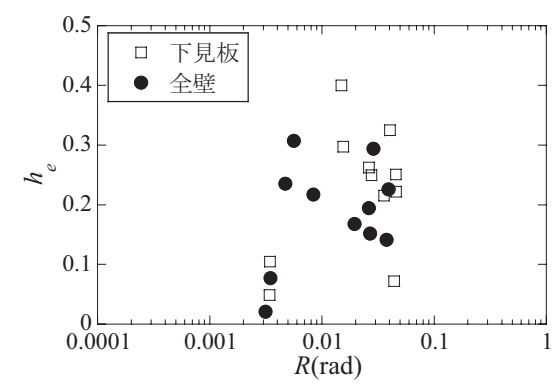

(a) 加振中の減衰定数 $h_{e}$

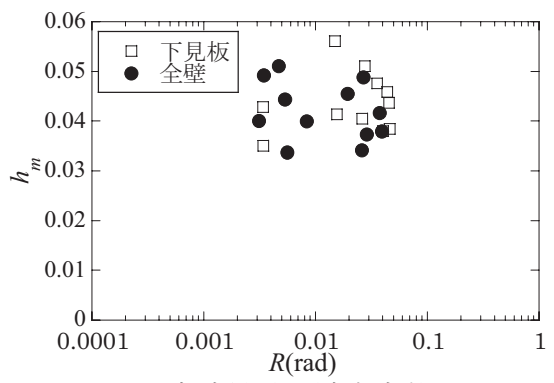

(b) 常時微動の減衰定数 $h_{m}$

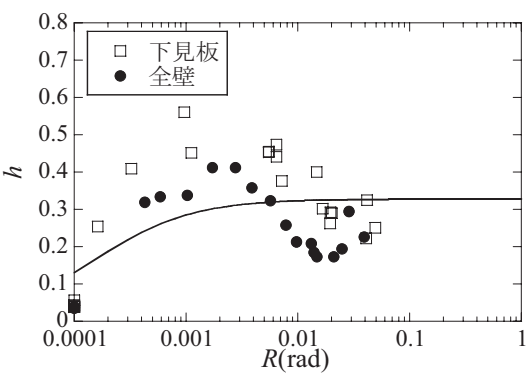

(c) 自由振動中の減衰定数 $h_{f}$

図 16 変形角 - 減衰定数関係【下見板・全壁試験体】 
造軸組試験体のうち、壁を主体とするか否かによって振動特性の振 幅依存性が異っていたため（図 13,14 参照）、軸組・差鴨居・垂壁差 鴨居・垂壁試験体の軸組を主体とする 4 試験体と、下見板・全壁試 験体の壁を主体とする 2 試験体に分けて検討を行う。なお、下見板・ 全壁試験体は加振波 No.1, 2( $\left.T_{p}=3.0,2.0\right)$ などの応答が小さい場合は自 由振動の信号がノイズに埋もれてしまうため、回帰に用いない。

はじめに、加振中のピーク振動数 $f_{e}$ 及び加振後の常時微動のピー ク振動数 $f_{m}$ を用いて、固有振動数の振幅依存性について検討する。各 加振について、 $f_{e}$ 及び $f_{m}$ と加振中の最大変形角 $R$ との関係を式(6),(7) を用いて回帰寸ると、回帰パラメータは表 3 のようになる(図 13 , 14(a),(b))。前述のように、軸組が主体となる試験体については、固有 振動数 $f$ を実験前の固有振動数 $f_{0}$ で除して無次元化したものを 2 乗し、 剛性比として検討すると、軸組に差鴨居や垂壁が加わっていても概 ね同一に回帰できることが分かる。一方、壁を主体とする下見板・ 全壁試験体の $f_{e}$ についての回帰式(6) は、全ての点について回帰する と $R_{e}=0.0028$ となり、 $R=1 / 100$ を越えるような場合の固有振動数の急 激な低下を表現できていない。そこで、比較的小さな変形角の影響 を無視し、 $R=1 / 100$ 以下の点を除いて回帰した結果 $R_{e}=0.00090$ となる。 また、自由振動中の固有振動数 $f_{f}$ の振幅依存性を式 $(8)$ を用いて回

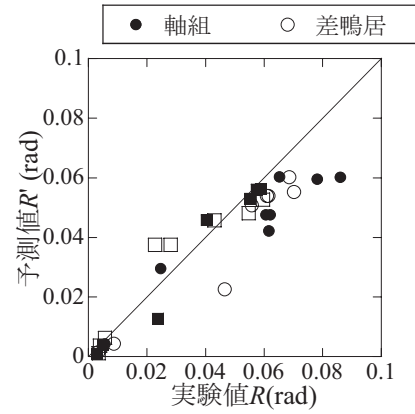

(a) 正弦波パルス

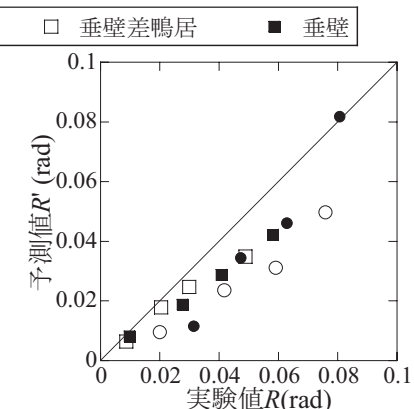

(b) 告示波
図 17 最大応答值の比較

【軸組・差鴨居・垂壁差鴨居・垂壁試験体】

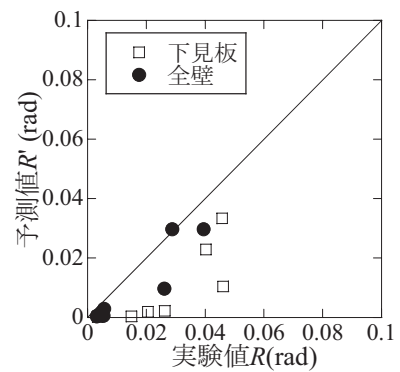

(a) 正弦波パルス

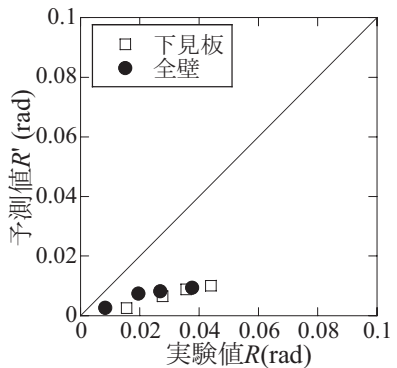

(b) 告示波
図 18 最大応答值の比較【下見板・全壁試験体】 $\left(R_{e}=0.0028\right)$

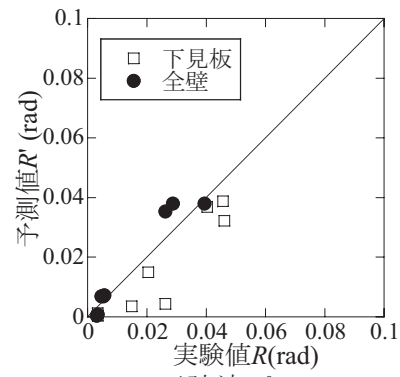

(a) 正弦波パルス

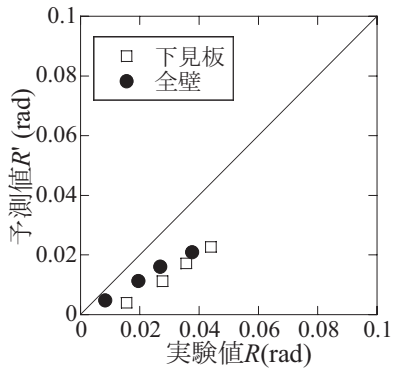

(b) 告示波
図 19 最大応答值の比較【下見板 - 全壁試験体】 $\left(R_{e}=0.00090\right)$
帰すると、回帰パラメータは表 3 のようになる(図 13，14(c))。ただし、 図14(c)のように下見板・全壁試験体で計測值が少ないのは、減衰が 大きく自由振動部分を十分に確認できなかったり、自由振動部分の 信号がノイズに埋もれた計測結果は除外しているためである。

以上をまとめると、固有振動数の振幅依存性評価式は、軸組を主 体とする木造軸組試験体と壁を主体とする木造軸組試験体の 2 種類 に分類して表現することができた。

\section{3 減衰定数の変化}

加振中の減衰定数 $h_{e}$ および加振後の常時微動の減衰定数 $h_{m}$ と $R$ を 比較したものを図 $15,16(\mathrm{a}),(\mathrm{b})$ に示す。 $h_{e}$ および $h_{m}$ の振幅依存性につ いては不明確であるが、それぞれ概ね $0.05 \sim 0.40$ 及び $0.01 \sim 0.06$ の間を 推移することが分かる。

また、前章で説明したように、自由振動中の振幅のピーク值の対 数減衰率を用いて減衰定数 $h_{f}$ を求め、式(11)を用いて回帰すると、回 帰パラメータは表 3 のようになる(図 15，16(c))。式(10)は、式(11)と 加振中 ・加振後の減衰定数の概算值から下限を $h_{0}=0.05$ と定めて回帰 式を求めている。

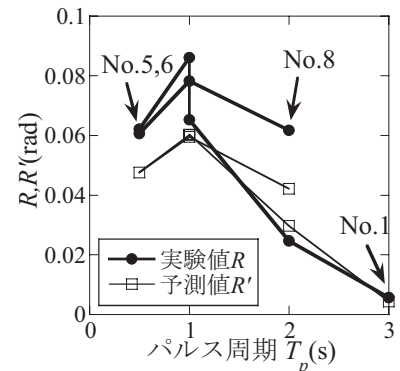

(a) 正弦波パルス

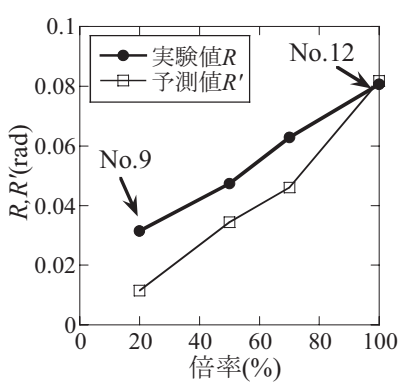

(b) 告示波
図 20 最大応答值の比較 (軸組試験体)

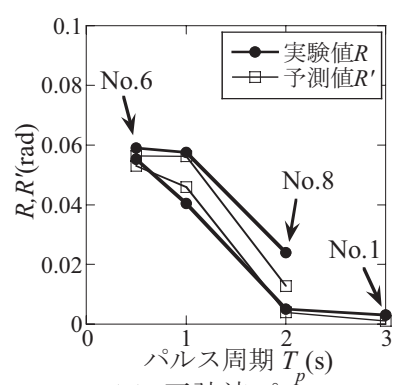

(a) 正弦波パル゚

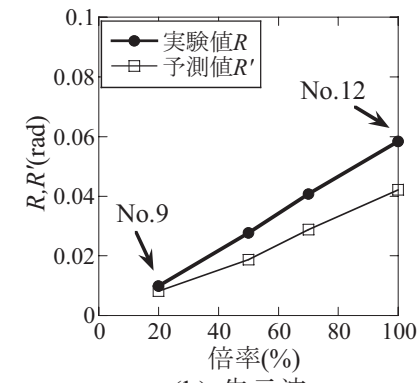

(b) 告示波
図 21 最大応答值の比較（垂壁試験体）

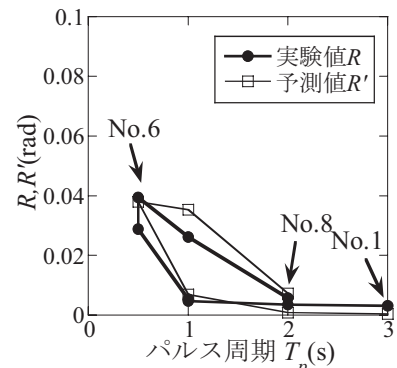

(a) 正弦波パルス

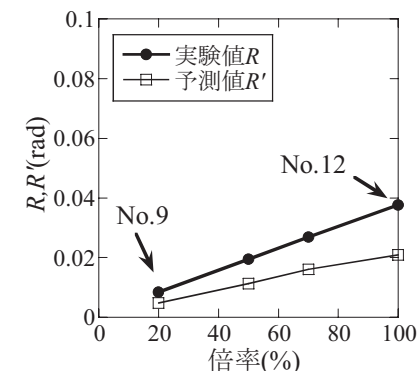

(b) 告示波
図 22 最大応答值の比較（全壁試験体， $R_{e}=0.00090 ）$ 


\section{5. 最大応答の簡易評価結果}

式(5)の固有振動数と式(10)の減衰定数の振幅依存性の評価式を式 (3) に代入し、応答スペクトル法に適用寸ることで最大応答の簡易評 価を行う。ただし、式(5)の $K$ は剛性比としているため、式(12)を用 いて固有振動数に変換して検討する。

$$
f=f_{0} \sqrt{K}
$$

振動台実験での各加振の最大変形角 $R$ の実測值と、本研究で提案し ている予測法で算出した最大変形角 $R$ 'を比較した結果を図 17 19 に 示す。ただし、評価式で用いる最大経験変形角 $R_{d}$ は、ここでは実験 值を用いる。これより、軸組・差鴨居・垂壁差鴨居・垂壁試験体の 4 試験体については、正弦波パルスの場合は、ばらつきがあるが概 㸚最大応答を予測できていることが分かる。告示波の場合は、やや 小さめに評価する傾向がある。全壁・下見板試験体の 2 試験体につ いては、加振中のピーク振動数 $f_{e}$ に関する回帰式(6)のパラメータを $R_{e}=0.0028$ と寸ると、図 18 のように大幅に応答を過小評価する。全面 に壁を持つ試験体は、脆性的な破壊により耐力が急激に低下し固有 振動数が大幅に減少するが、与えたパラメータでは急な固有振動数 の低下を表現できていないためと考えられる。そこで、 $R=1 / 100$ 以上 について回帰したパラメータ $R_{e}=0.00090$ を用いて評価すると、図 19 のように告示波の場合はやや小さめに評価する傾向があるが、予測 值が実験值に近づくことが分かる。

次に、入力波による違いを検討するため、図 20 22 にパルス周期 $T_{p}$ 及び告示波の倍率をそれぞれ横軸に、最大変形角を縦軸とした軸 組・垂壁・全壁試験体の応答予測結果を例示寸る。図中の番号は表 2 の加振番号を示寸。図 20 22 の各試験体における $T_{p}=2.0$ の(入力波 No.2，8)ように、本予測法を用いれば $R_{d}$ の変化（被災経験の有無）に よる $R$ の増加を追跡できることが分かる。

\section{6.まとめ}

本研究では、常時微動計測で推定した固有振動数に基づく、過去 の地震で経験した最大変形角による固有振動数の低下を考慮した、 想定地震動に対する伝統木造建物の最大応答（変形角）簡易評価法 の提案を行った。また、正弦波パルスを入力した振動台実験を実施 し、固有振動数及び減衰定数の振幅依存性と過去に経験した最大変 形角が固有振動数に及ぼす影響について定量的に把握するとともに、 実験結果に基づく提案最大応答予測法の精度検証を行った。

得られた知見を以下に示す。

1) 本論文の範囲内では、軸組・差鴨居・垂壁差鴨居・垂壁試験体な ど軸組を主体とする試験体と、全壁・下見板試験体など壁を主体と する試験体とで、単位軸組架構の初期剛性や剛性低下の振幅依存 性の違いに応じて固有振動数の振幅依存性が 2 種類に大別され、 それぞれについて実験結果の回帰を行い評価式の構築を行った。

2) 実験結果と比較して提案予測法の精度検証を行った結果、正弦波 パルス入力試験で得られた最大応答を概ね予測できた。ただし、 正弦波パルス入力試験後に実施した告示波入力試験の結果は、最 大応答を小さめに評価する傾向が見られた。

今後は、様々な伝統木造軸組架構について振動台実験を実施し、 振動特性の振幅依存性に関するデー夕蓄積などを行う。そして、1) 本論文で実験の対象としなかった単位軸組架構に対する評価式の適
用性検討、2）単位軸組架構の評価式に基づく建物全体の固有振動数 振幅依存性評価式の構築方法の提案を行うとともに、3) 常時微動計 測から得られる固有振動数の季節変動 ${ }^{14)}$ や劣化度の補正法の提案、 適用対象の明確化などを行っていくことで、実際の伝統木造建物へ 適用可能な手法の開発を行いたい。

\section{謝辞}

本研究は、科学研究費補助金基盤研究(A)No.22246072（代表者：林 康裕）の補助を受けました。振動台実験を行うにあたり、元大学院 生の高橋遥希氏をはじめとして、京都大学大学院工学研究科建築学 専攻・建築保全再生学講座の学生の皆様には多大なご協力を頂きま した。ここに記して、深く感謝の意を表します。

\section{参考文献}

1) 国土交通省建築研究所 : 改正建築基準法の構造関係規定の技術的背景, ぎょ うせい, 2001.

2) 国土交通省住宅局建築指導課 他 : 2001年 度版限界耐力計算法の計算例とそ の解説, 工学図書株式会社, 2001.

3) 木造軸組構法建物の耐震設計マニュアル編集委員会 : 伝統構法を生かす木造 耐震設計マニュアル 一限界耐力計算による耐震設計・耐震補強設計法, 学芸 出版会, 2004 .

4）地盤工学会 地盤の動的解析一基礎理論から応用まで一編集委員会 : 地盤工 学・基礎理論シリーズ2 地盤の動的解析一基礎理論から応用までー, 社団法 人地盤工学会, 2007 .

5) 林康裕 : 性能等価応答スペクトルに基づく建築物の地震荷重評価, 第11回日 本地震工学シンポジウム, pp.651-656, 2002.11

6) Y. Hayashi, A. Nii and T. Morii : Evaluation of Building Damage Based on Equivalen - Performance Response Spectra, The 14th World Conference on Earthquake Engineering, Oct., 2008.

7）鈴木恭平, 川辺秀憲, 山田真澄, 林康裕 : 断層近傍のパルス地震動特性を考慮 した設計用応答スペクトル, 日本建築学会構造系論文集, No.647,pp.49-56, 2010.1.

8) 山田真澄, 鈴木 祥之, 後藤正美, 清水秀丸：単位木造フレームを用いた動的・ 静的実験による木造軸組の而震性能評価, 日本建築学会構造系論文集, No.582, pp.95-102, 2004.8

9) 森井雄史, 宮本慎宏, 高橋遥希, 林 康裕 : P $\Delta$ 効果が木造軸組架構の変形性 能に及ぼす影響, 日本建築学会構造系論文集, No.650,pp.849-857, 2010.4.

10) 杉山亮太, 鈴木祥之, 後藤正美, 村上 博 : 乾式土壁パネルを用いた木造軸組耐 力壁の開発, 日本建築学会技術報告集, 第23号, pp.149-154, 2006.6

11) 柴田明徳 : 最新耐震構造解析, 森北出版, 1981.

12) 田中幸雄, 佐々木淳, 塚越治夫 : RD法による構造物のランダム振動時の減衰 評価, 日本建築学会構造系論文報告集 第454号, pp29-38, 1993.12.

13) Hardin,B.O. and Drnevich,V.P. : Shear Moduls and Damping in Soils : Design Equations and Curves, Proc.ASCE, SM7, pp667-692, 1972.

14) 森井雄史, 井田祥子, 新居藍子, 林康裕 : 微動計測に基づく京町家の簡易耐震 診断(その1，2), 日本建築学会大会学術講演梗概集 構造III, pp.121-124, 2008.9.

15) 杉野未奈, 浪江和隆, 高橋遥希, 宮本慎宏, 多幾山法子, 林康裕 : 地震時におけ る伝統木造建物の振動特性変化と最大応答の簡易予測, 日本建築学会近畿支 部研究報告集 第51号 構造系, pp.409-412, 2011.6.

16) 杉野未奈, 浪江和隆, 高橋遥希, 宮本慎宏, 多幾山法子, 大西良広, 林康裕 : 伝統 的木造建物の地震時挙動評価に関する実験的研究（その2）常時微動計測結 果に基づく最大応答予測, 日本建築学会大会学術講演梗概集 構造III, pp.393394, 2011.8.

(2011年 6 月 10 日原稿受理，2011年11月11日採用決定） 